\title{
Is There a Literature From the State of Amazon?*
}

Francisca de Lourdes Souza Louro

University of the State of Amazon, Manaus, Brazil

\author{
Jamescley Almeida de Souza \\ Federal University of Amazon, Manaus, Brazil
}

\begin{abstract}
I have chosen this title because it represents a question which floats over the existence of literariness in authors from State of Amazon. Literariness, from Jakobson's viewpoint, is the number of proprieties which characterizes the literary language. In this regard, the literary text distinguishes itself for the fact of transforming realities and for use it as model to create "fantastic" worlds, which exist only in the texts, once they set up themselves through metaphors, caricature, allegory, and likelihood. Formalists declare that the object of literary science must be studied from the specific particularities that differentiate the literary objects of all other subject. There is a book, written by the poet Jorge Tufic, which raises that same question, and finally responds: "there is a lost language which must be recovered" to better understand that we can be a new research and creativity field. I have chosen then, for this study, three tales of the writer Arthur Engrácio to discuss this question. It is aimed at contributing, in a general way, to the knowledge of the literature produced by Engrácio, as well as to extend it to other perspectives heretofore little studied.
\end{abstract}

Keywords: literariness, tale, caboclo, language (literature), literary science

\section{Introduction}

In Is there a literature from the State of Amazon?, Jorge Tufic (1982) declared that "the history of literature of the State of Amazon has not yet been written" (p. 12). He also pointed out that it is "from the business cycles, such as the cocoa and rubber cycles, that we can see the measurable presence of fiction writer involved in the dominant situation" (Tufic, 1982, p. 12). From then on, Tufic listed thinkers and naturalists such as Alexandre Rodrigues Pereira, Bento de Figueiredo Tenreiro Aranha, and Lourenço da Silva Amazonas etc., which have greatly contributed to that culture.

Founded in 1930, the Literary Society was followed by the Intellectual Amazon Society, whose founder and president was Leôncio de Salignac e Souza, owner of A clava, a single number magazine. Thenceforth, we took a leap to the Early Morning Club which is the set reference factually or by law to talk about the literature produced in the State of Amazon. As of public knowledge, on 22 November 1954, the Early Morning Club was founded, bringing with it a high number of figures such as: Farias de Carvalho, Luiz Bacellar, Violeta Branca, among

\footnotetext{
* Acknowledgements: I would like to express my gratitude to Jamescley Almeida de Souza for his translation of my paper "Será que existe uma literature amazonense" from Portuguese into English.

Francisca de Lourdes Souza Louro, Ph.D., assistant professor at the Technology-Mediated Bachelor of Arts in Letters, Normal School, Department of Portuguese Language, University of the State of Amazon, Manaus, Brazil. Research Interests: Hermeneutics, Poetics \& Amazon Literature.

Jamescley Almeida de Souza, master of Letters in Portuguese Literary Studies, Federal University of Amazon, Manaus, Brazil. Research Interests: Amazon Literature, Sacred \& Imagery.
} 
others. It can therefore be seen that there is a literary history in its dynamic temporality and its initial journey was recorded by the "publication of the twentieth year legal status in the Jornal do Comércio, on March 3, 1974" (Tufic, 1982, p. 39).

Then, as regards the question if there is or not a literature from the State of Amazon, I simply reply: No, there is not. There is, undoubtedly, a Brazilian literature produced by writers from the Amazon and, as it is known, through what Geography shows, the State of Amazon is in the northern of Brazil. In these circumstances, I have chosen a northern author to dialogue with the tales produced in the city of Manaus, seeing in Arthur Engrácio a possibility of literary response due to his texts. We should not forget, by the way, what Ricoeur declared, namely: "the text speaks about a possible world and a possible way of someone guiding oneself in it. The dimensions of this world are really open and known by the text" (Ricoeur, 2000, p. 99), once the meaning of the text is not behind the text, but it is ahead of it. Furthermore, only the man has a world and not just a situation.

Accordingly, to comprehend a text is to follow its movement of meaning to capture the reference of what it says, of what it talks about. This is the role of the mediator: to do this is to look the underlying subjectivities of text.

Somewhat of Arthur Engrácio's literary production is in the following works: Histórias do submundo (1960), Antologia do novo conto amazonense (1971), Restinga (1982), A berlinda literária (1976), Ajuste de contos (1978), Contos do Mato (1981), Um olho no prato outro no gato (1981), Os pingos nos ii (1983), Estórias do rio (1984), Áspero chão de Santa Rita (1986), 20 contos Amazônicos (1986).

As we can realize, Engrácio's preferential literary field is to write tales, whose background is the life in Amazon. To say that the representation of that Amazonian life expresses its society is obviousness. There was a time, however, that such representation was a novelty and something historically considerable. In Engrácio's works, for example, we can analyze the social content, generally having some moral and political reasons as basis. Practically, this means to state or to imply that the art must have a content of this type, as well as that it is the measure of its value. This does not mean, however, to carry out a sociological analysis, but to embrace a philosophical hermeneutics approach, according to Ricoeur.

For this study, I have selected three tales which can be found in the work 20 Contos amazonicos, to present the literature done by an author from Amazon. To put it better: the "literature from the State of Amazon", henceforth "Amazonian literature", hoping that the readers can verify if these tales have literary characteristics.

The question, here, is how Engrácio represents, in the pages of his fiction, what transcends in importance, and what appears related to concerns about the significant cases and experiences occurred in the life of the man who lives in rural areas. What is at stake is not only the fact of the characters who appear in the narrative exist indeed, once what we appoint being the literary text has the subject created in and by the narrative. Seen in these terms, literature is a semantic event, as it projects an imaginary world what includes narrator and the implicit reader.

This conception on literature as fiction is not, nevertheless, fully exact because literary works also represents historical and psychological realities. Consequently, we can say that a work is related to a possible world among several possible worlds, more than to an imaginary world. Faced by this situation, we arrived at the conclusion that literary discourse, possessing the conditions of utterance different from the other linguistic acts, is linked to specific conditions, that is, to find in the work a complex and intense organization which is expressed in the language (literature). 
What is indeed at stake is a set of problems that the author felt and, thus, reproduced acutely throughout of his life as writer, such as: the problems of literary sources, the problem of relation between the created work and these sources, the rigor of background which is framed the fiction, as well as, naturally, the difficulties in relation to stylistic effects, which are also felt intensively by the heroes of Engrácio's tales. We know that the actions of scenes, of dramas, and of narrative focus are always in the Amazonian space, but this does not constitute a problem, among other reasons because the winner of three Brazilian literary awards (Jabuti Award), Milton Hatoum, chose that same space to discuss the problem of existence in his novels and tales. What do make them equal? Both of them elaborate critic texts with character that populate the literary tradition and bring us close to the impression that they really existed. Literature carries with it the temporal dimension, becoming immortal and capable of talking eternally about the numerous possibilities of existence of man in the world. Hence Aristotle saying that being good at creating metaphors meant to have sharp eyes to look the similarities. Having said that, let us go to the tales.

\section{Caboclo Intrigues}

This is one of Engrácio's texts that possess social critic characteristics about the life of caboclo, that is, the native Amazonian man. It shows the nature which arrives at the Romantic art through a land-based description of a protagonist affected by the evil of love. Clementino, the caboclo of the work "Cismas de caboclo" (Caboclo Intrigues), fell in love with Mariazinha, and for this reason he made all necessary efforts to go and meet her.

In this tale, Engrácio draws attention to the difficult conditions lived by the caboclos, establishing a subtle language game, as a form of bringing close the narrative to the reader's reality, which reflects over the proposed topics in the narrative, namely: youth's desire by love, the mother, a woman left lonely and dependent on her only son; the maternal and filial instinct; the distance of Amazon which is represented by adverbs; the representation of nature, expressed in the elements that show Mariazinha's femininity; the intertextuality; the narrative style, full of oral language; the hidden desire of flying; the travel topic; phallic symbols; the song of the cicadas calling to natural mating; the magnitude of the waters; a language close to caboclos, executed by means of adverb abuses to demonstrate the love; the amorous suffering; the presence of animals in the house; the female loneliness; food as representation of social status; common acts of the caboclo life; the smoking addiction as a distraction; the house and its yard and everyday junk; the scape and the time marked by the summer, as well as the awakening to the choice, and the familiar abandonment.

The sexual question is worked by the author in order to symbolize the search for unity and the decrease of tension that emerge in the characters. The amorous and sexual intensity is accentuated by the representation of the elements, when:

Out there, the cicadas temper their throats, feasting the sun which announces to them a long and peaceful summer; in the trees, the cicadas twitter incessantly, spreading their song by the surrounding space in an excitement of rhythms and fanfares and everything vibrate with the magical touch of the king of light. Plants, birds, trees, waters whose waves, in a sensual swing, thank sun by the gift received. (Engrácio, 1986, p. 33)

Chevalier (1990) stated that the song which rises in a representation of amorous seduction is a symbol of the word that unites the creative power and its creation. It is necessary to hold on to the mast of will and of reality, as Ulysses did, in Odyssey, with the purpose of not to fall into the disgrace of the song which leads to a world of 
passions and illusions. Clementino, however, did not resist listening to the cicadas twitter the winter, a hot season in Amazon, with a term of duration of four months. This is the time of the representation of Clementino's passion for Mariazinha. The sun also rises as an ambiguous and immortal element, appearing as a metaphor of intensification of the passion. In fact, the heat emanated for him warms up the human nature that is shown in the vital feeling of happiness, that is, the experience of the love between them.

It is from Mariazinha that emanates a light which falls over certain angles, whereby the narrator highlights the reliefs proper of the youth. Clementino does not resist to the song:

Of the cicadas which twitter incessantly; in the trees, spreading their song by the surrounding space in an excitement of rhythms and fanfares. It is no wonder that Clementino, after hearing so many twitters, got marveled with that climate! He rose up, lit a cigarette, and moved toward the edge of the canyon from where, lengthening his sight up to the point she could reach, he imagined himself in Mariazinha's house, in Tapir's Clay Pit, a very long journey up the river. He thought about the night he met her, during a pagoda in Anastácio’s house. (Engrácio, 1986, p. 34)

The semantic density shown with the meaning of the distant inland highlights the character, when text says: "and move toward the edge of the canyon from where, lengthening his sight up to the point she could reach". It is certain that the images are impregnated by the corporal dimension, once "everything vibrate, unless Clementino", typifying him for his unique actuation. More clearly, before he offers himself to his consciousness as an external object to be known, this image awakens the soul, arousing not only internal movements or asleep ideas concerning worldly objects, as well as elements present in the human interiority, when: "he was unable to imagine this thing, that she come coming, come coming and ended up resting on deep inside of his chest" (Engrácio, 1986, p. 33).

With this in mind, I found in Sartre (1984) the idea about "the image (as) owner of the unusual propriety of motivating the actions of the soul" (p. 39). What we see is the young Clementino's body full of stimuli to motivate his future action, namely: to scape to the arms of love. It is important to stress that Foucault (2001) commented on the "sexuality as emergency of an event of multiple value in our culture" (p. 77), since in the words of Engrácio: "memory caused him a slight shudder in his body, increasing the desire of seeing her" (Engrácio, 1986, p. 35).

It is important to understand the clear romantic nationalism in Engrácio's work, a point ignored by many researchers. Perhaps it is because they do not consider the written world as a wide symbolic unity formed by small unities of philosophical, scientific, artistic, and literary intelligence. Engrácio's work collaborates to possible researches about the linguistic field if appropriate to observes of the literary art. Let us look at the evidence: “eat more, son, are you not enjoying the meal?" (Engrácio, 1986, p. 33).

For us, only everyday events emerge in the Amazon in a poetic manner and full of richness. To examine how Engrácio inserts man in the relation of life, as well as poetic element, once that "only by the other people's narrative we know our unity. In the thread of our (possible) story told by others, we end up, year after year, becoming like ourselves" (Bachelard, 2006, p. 77).

In the representation of the "old lady" Satuca, no one can deny that appears a striking feature from the Amazon. Let us see: "she smoked, looking at her son, who remained in the same position; looking at him and meditating" (Engrácio, 1986, p. 34). A low vision woman, with total inversion of life experience: realities of the world developed into memories and dreams, and these one started to compose the absence of beauty, household 
tasks, and the smoking addiction to fill the emptiness caused by loss of loved. Even the name proposed by the author serves "to break the straightness of discourse, as much as it is ambiguous, once the ambiguity of sign in depth tends to be an ideogram, a sign" (Pignatari, 2004, p. 119).

The character's old-age reflects a sign of wisdom and of virtue, still more in the sense of the mother who carries all the experience and all the rites that life has. Regarding "old lady" Satuca, this rite starts with the duty of having a baby, as well as she works hard in a rhythm through which everyone has to pass. Satuca, in the line of succession, aligns herself in the definitive past, not more as the first, but in a present that restarts at every moment.

Life, in this Engrácio's tale, is a ritualistic and periodic repetition as an ancient heritage. In Eliade's philosophical view, "the historic world, the societies and civilization built with the hard efforts of thousand generations, all this is illusory, once in the plans of cosmic rhythms the historic world lasts a brief moment in time" (Eliade, 1991, p. 64). Engrácio clarified this point in the following excerpt, when he showed that family stands for reason and love stands for desire, according to his exalted imagination, driven by memories of the night when he lay with Mariazinha:

At the height of the excitement, he laid her down right there, over the foliage, and he went in unto her, brutally, manfully, and the feeling of relief ran quietly along his testicles. The memory caused him a slightly shudder in his body, increasing the desire of seeing her. The longing beat in his chest as strongly as the waters during the floods of the Amazon River - indomitable, cruel, and impetuous. (Engrácio, 1986, p. 34)

We can see, by impetus of the imagery, the space question of this text which has a specific domain in the story. Engrácio develops the action in distant Amazonian inlands, by incorporating landscape elements in a clear theater of surrealism, achieved by the wonderment, by the euphoria of spirit, and by the freshness of the caboclo's soul in love.

In Clementino, emotions raised by memories make him revive the illusion of a present which is self-sufficient to him. His emotions are more reflected than premeditated, which makes him unable to represent his life. All that remains is staging his life and living mechanically, orientated by useful habits of the reactions desired by him. The text, in addition, is clear about the character's undesirable appeals, which set up a notion of the family: "Undoubtedly we surprise ourselves with the fact of living two paralleled existences indissolubly united, but between which we do not set up a perfect agreement" (Paiva, 2005, p. 190).

\section{Roughly Traced Lines to Deusilene}

This other tale is pretty substantial, once in it, Engrácio makes use of the epistolary model, preparing the reader from the title. In "Roughly Traced Lines", then, Manduca, the textual subscribe of the letter, traces his life in the textual lines to Deusilene, his wife who stayed in the inland and now reads the urban actions of her husband. With regard to this tale, Angenot (1984) designated this type of narrative style of "metachrony", because the author modifies all the logic order of the series of events in narrative (foretaste, retardation, lacuna, narrative with inverted causal order). It is no longer a question of wanting to confuse the reader as having a narrator, a writer, and a reader, embracing the expressive support plan, which is the stylistic elaboration of the discourse. This is perhaps the most difficult tale to understand due to the succession of the actions which have past, present, and future. In a text, declares Fiorin (2008, p. 229): 
In the first place, it is necessary to say that, as all the events are temporalized, there is a micro-temporality which organizes the major sequences. Genette uses the term recit (narrative), which is polysemic, and may mean: a) the discourse that tells events, that is to say, the narrative utterance; b) the series of events which constitute the objective of discourse, that is, the content of the narrative, what has happening; c) the act of narrating, the narrative. Each one of these meanings corresponds to distinct "aspects of narrative reality". (Fiorin, 2008, p. 229)

Can this colorable narrative model be related to the difficulties of the literary work? Engrácio uses the city of Manaus as scenario, which is being transformed by the industrial expansion. A caboclo, for instance, is brought from Amazonian inlands to Manaus in search for work, a way of giving real effects to narrative, which is called by Ricoeur as "desire of a good life". In Time and Narrative, Ricoeur invited us to rethink the narrative, affirming that:

The ultimate challenge of the structural identity of narrative function is the temporal character of human existence. The world exhibited by any narrative work is always a temporal world [...]. Time becomes human time as far as it is articulated in a narrative way; by contrast, narrative is significant as far as it outlines traces of the temporal experience. (Ricoeur, 1994, p. 15)

This temporal dimension of the human experience is that enables us to comprehend, by literary narratives, the subject forms as well as how to interrogate and problematize ourselves and the others. It is in the light of this Ricoeur's postulate that Engrácio's narrative gives to the reader the opportunity to think about himself through the actions of the textual characters as well as to realize a narrative inside the other, text on text: "eighteen days have gone, and until that moment the police had not discovered if the doctor was alive or dead. Despite all the evidences and traces led police to admit that Ida was really murdered by her lover Evaldo" (Engrácio, 1986, p. 109). This is the note published on the newspaper and read by Clementino when he was in jail.

The time of the utterance plan implies the existence of two temporal moments, relatives and complementary: the time of I that speaks in the past: "it was in the third day that I arrived in Manaus", as well as the time of the present, in the moment of the writing: "I write you, Deusilene, from Doctor Boaventura's house".

We have, in this text, what Vitor Manuel calls of analepsis, once the beginning of the plot do not match with the beginning of the tale: there is a retrospection of the facts, once the tale is narrated in the form of a letter, in soliloquy. The letter is a strategy used by the author to the reader, and through which he confesses us the suffering and the pain that lives in character's soul. It is through that strategy that is revealed the longing, anxiety, and hopelessness, which are skillfully unraveled. Hence, protagonist's intimate world is set up by the Cervantes's sign, major archetype of burlesque, of imponderable.

We can realize in the narrator a type of filmography resource, when he presents, during his tour, the downtown area in Manaus:

I went bar hopping, along the pubs, along the squares; I went by the so called Amazon Theater, by the Justice Palace, and by the other buildings, huge ones, that we have here and led me astonished, wondering how everything was beautiful. In the business streets I stopped to see the goods that the owners put in a window with a big glass at the front, which they called showcase. (Engrácio, 1986, p. 109)

We realize how it is colorable to show the Amazon Theater, which, in the golden days, was the stage of many shows. In front of the Amazon Theater stays the Justice Palace, where in the past was decided the Amazon people's fates. Finally, it is shown the showcases, in downtown, which represented, in the golden days, the wealth of the city. 
This tour brings back the installation of the Manaus Free-Trade Zone, where the touristic guide is Clementino, helping readers today to make the reconstitution of the city that once existed.

We can say that it is a colorable text about complaints related to slavery, sexual exploitation of children, and state apparatus. The latter appears in the figure of delegate Piragibe, who put Clementino in jail to respond to society about a crime committed by other person. What is much more interesting is to use the figure of Pimentel, a subject who is seen as a social parasite, always ready to take advantage of any innocent to explore the city. When he is unemployed, for example, he went out to find a friend: "I went bar hoping, along the pubs, along the squares".

Faced with reality, the inland man exceeds the immediate possibilities offered by real, represented here by the industrial development as model of financial stability to the Amazon. Being the caboclo influenced to recreate new myths and new beliefs, he starts to see the magical — in this time of narrative — in the financial development, which promises wealth as draws attention to the city, leaving the life of purity lived in Amazonian inlands. Hence, we can conclude that Engrácio's authorial message is clear: inland man must not go out of his space to venture himself in the big city when he does not have sufficient knowledge to live between the "beasts" produced by society.

Engrácio starts from one simple reality: to speak about the life of the man who deals with economic and social problems in the inland of Amazon. Some authors structure their texts to readers, showing ostensibly the conditions of references. In the same way, the text releases its meaning from the guardianship of mental intension as well as its references of the limits of the situational references. What Engrácio describes creates meaning, making us to imagine how the life of the people who are represented in these reports is. According to Ricoeur (2000), this is what "Heidegger rightly says about Being and Time, namely, just writing reveals this way of being in the world, as well as the fate of the discourse, as if projecting a world" (p. 49).

In these adventures or misadventures, we see some common portraits of the many "Manducas" who arrived in Manaus, utopian dreamers, believing in possible friends, but finally became victims, and experienced embarrassing situations. In all innocence, Manduca fell into an adventurous trap, together with a friend who presented himself as a touristic guide. This new friend, Pimentel, leads him to live the most incredible adventures in places never seen before. Pimentel, for instance, guides Manduca to know the long dreamed Manaus Free-Trade Zone, as well as prostitution zones. Manduca is moved when he sees girls with an air of innocence in the Saramandaia Brothel. In questioning the young age of the girls, Pimentel warned him: "here, the prostitution of little girls is so high and open that teenager twat does not know any virgins, because when one arrives, other one has already been there" (Engrácio, 1986, p. 108).

This is an event that belongs to a current of consciousness which reaches the reader as experienced experience, as if it was lived; however, it was private and became public. Engrácio reaches the reader with evidences of this nature in almost all the tales, allowing us to express that this is his brand, his discursive reference, once he speaks with objectivity in the language used in the Amazon region.

In this tale, the author reports the anguish of the fleeting achievements, of the disappointments through which human existence undergoes. The narrated situations are mere pretext to put characters on stage, thinking about themselves and about the others, as well as feeling profoundly the life in its happiest, saddest, and indefinable aspects, as time goes by. Ricoeur added that it is a role of the reader to comprehend and not "just 
repeat the discourse in a similar event to generate a new event, which starts with the text in what the initial event had as aim" (Ricoeur, 2000, p. 87).

Looking around, the narrator allows the reader to comprehend an era, a historic reality being critically represented, once the drama of each individual resounds in collective life and represents the community. The reality atmosphere implies objectivity in fable making, once that who is narrating is a witness to the events, in an appropriate and close language. Fictionist visualizes the linguistic overview in a narrative, making it closer to the reader, that is, the language is concrete, objective, and direct in the language of Amazonian man.

The historical context used is marked by the economic growth crisis in the region, by the emergence of new classes in Manaus society, as well as by the appearance of a new and overjoyed belief in the rising technological progress. This is the realistic process related to the diligence on the part of author to configure the space and the customs, when he uses an unable migrant as protagonist to be observer of an expressive period. Everything in the tale happens intensely and everything else is cause and consequence of this central event.

\section{A Unique Tour in the Belly of the Big Snake}

The third tale has a different proposal, since it brings an Amazonian characteristic of retelling the poetics of imagery about the web of relationships as well as the human stories. Although fully visible, the manifestation of the unchanging identity of that one who speaks and acts retains a certain curious intangibility that frustrates all attempts of distinct verbal expression. In the tale "A Unique Tour in the Belly of the Big Snake", Engrácio brings, as the center of the story, an individual experience fact, which it is known from the cradle to the grave by people of Amazon: the art of telling stories of the Amazonian communities. Let us see: "talk about the Curupira, buddy [...]. Tell that story of Matintaperera ${ }^{1}$ [...]. And what about that story of Big Snake, how was it?” (Engrácio, 1986, p. 81).

This way of showing culture has its origin in the oral tradition horizon. In this narrative, for instance, Engrácio highlights, by the myths and legends view, the presence of the story teller and the listener/buddy, reporting the disbeliefs of the philosophical and literary truths: "such a tourist for whom I had told a story about the Big Snake, he was in a suspicious way, looking askance at me, with an ironic smile around the corners of his mouth, putting in doubt my report" (Engrácio, 1986, p. 81). Loureiro (2001), in this sense, declared that in the "Amazonian life mythology reappears as an appropriate language of fable, which runs as a product of a natural faculty, led by the senses and imagination" (p. 130).

As Semiotics is an inquiry about the nature of signs and its relations, meaning a sign all that represents or substitutes something, in a certain measure and for certain effects, Pignatari places:

The spoken word among iconic signs, although this founding language of the culture and of man himself must perhaps today be situated between the written code and the audible iconicity. Written language, literary or not, sees itself cornered by the others codes and sign makings. The called written word crisis is but a crisis of a signal system, which is obliged to recognize its own limitations. It is the crisis capable of generating freedom and creativity. But Semiotics leads us to suppose that narrative discourse is a false logic discourse. (Pignatari, 2004, p. 114)

As we can see in Engrácio's narrative:

\footnotetext{
${ }^{1}$ It is a very common legend in the Northern region of Brazil, which talks about an old hag who turns herself into an ominous bird during the night.
} 
- These people there from the south, full of kindness and knowledge, have the habit of ironizing everything that we tell about the events that take place here, in this wide world of land and water, where we live...

- Such a tourist for whom I had told a story about the Big Snake, he was in a suspicious way, looking askance at me, with an ironic smile around the corners of his mouth, putting in doubt my report. Why I'd lie for you, buddy? What need I have to make up stories if things happen itself?

- But he said it straight to your face that it was a lie, buddy?

- No, but he supposed.

- But what an arrogant bastard, huh? And that story about Big Snake, how was it? I didn't know...

— Didn't you know? I don't like to remember it. It was an awful thing. It seems that I'm still seeing that squamous and full of mud animal, sinking in the middle of the lake.

— Remember the story, buddy, and go telling me, nice and slow. What a thing, huh! (Engrácio, 1986, p. 81)

This is a text that highlights the language, once we know that:

In poetics and in linguistics there is an ephemeral limit, place of dispute and of interaction of the two sciences, whose objects overlap in the discourse. The discourse, rather than being seeing as "home of being", such as a philosopher once designated, it is much more a "look of being", since its nature depends on subject's point of view that produces it. (Teles, 1996, p. 19)

We can say, therefore, that the author does not create any word, but he works with the signifiers of the common language, which, however, receive an increase of rhetorical information, becoming literary signifiers. It is from there that Semiotics takes advantage of the linguistics conclusions for the literary discourse analysis. However, in making this consideration, we are not going to take the way of Semiotics or of Linguistics. On the contrary, we chose to understand text as a resource of remaking the Amazonian man's image, represented by the art of telling his stories and beliefs, passing them on through the narrative act and the recreation of culture.

Based on what was described above, that is, the emphasis in the remaking, in refinishing the art, transforming literary work in a monument of word, and consequently a way to remember, we can that all of this is an attempt to prevent memory from dying. Engrácio's work is, in its axial lines, an obsessive reconstruction of a universe surrounded by the threat of calamity, as well as the oblivion of the world which one day the author was part. Engrácio was an Amazonian man, like many of us.

It is not a Proustian search, but we can say that the narrative art in Engrácio cannot be a "Lost Good", once this good is not only an ethical utterance which indicates the writer's personal journey, as well as it is the line that falls within a world perspective founded in an attentive observation of Manaus society and human condition. Culture is society's greatest good and this good cannot stay lost in oblivion. It is necessary to improve this good, once it is also based on language reconstitution, that is, the constellation of the necessary terms to its dissemination.

The Big Snake legend appears in some authors as "Cobra Norato" or "Boiúna". There are numerous narrative appearances of this legend, once it is one of the best-known legends, being also studied by the Brazilian folklorist Câmara Cascudo, in his Geography of the Brazilian Myths. Loureiro, for instance, confirmed the proverb that says:

\footnotetext{
${ }^{2}$ In Tupi-Guarani language "boiúna" means big snake.
} 
The rivers of Amazon are timepieces and calendars to the people from this region. Life looks at the river, as well as men adjust their daily life by the water movements. In a region of vast tracts of land, endless lands, the Caboclos have to be attentive to the natural landscape, because it is from this intimacy with nature that results the knowledge about their existence. (Loureiro, 2001, p. 93)

In this Engrácio's narrative, there is what we call the intertextuality. Be aware that the narrator is swallowed by the Big Snake just as the biblical character Jonah "prayed into the Lord out of the fish's belly, and said: "I cried by reason of mine affliction unto the LORD, and he heard me; out of the belly of hell cried I, and thou heardest my voice" . In Engrácio's tale, the character also shows his religious feeling, falling back upon the Divine Holiness:

If Virgin Mary was a person of being worried about the things we ask her, she would have send me to hell at that time, because of the intensive way I called on her holy name. Terrified, I asked her to take me out of that darkness, which could only be the Devil's address. I had never seen such wraith. Where was I? ... Sitting in canoe's seat, I kept thinking of: how that cursed swallowed me without I feel any pain? I placed my head between my hands and I started to pray. I called on again Our Lady of Immaculate Conception; I made a thousand of promises. (Engrácio, 1986, p. 82)

Chevalier conceptualized that the Big Snake presents a complex of archetypes linked to a cold, sticky, and underground night of the origins. We also have the Greek reference, where we find that:

Laocoön was punished by the snakes sent by Apollo and Dionysius. Apollo, the sunniest, the most Olympian, freed The Oracle of Delphos from the hypertrophy of natural forces which is the Python Snake. Dionysius, on the other hand, appears as the great liberator of the human nature from the reason dictatorship, that one who will give birth to Gnostic sects, and to an entire category of heresies that will fight against Roman Church. (Chevalier, 1990, p. 176)

Taking into account what was described above, a question remains: Does the text try to penetrate into our social environment through what existed before us? That may be. Actually, we accept be animated by ancient and new images to wonder the kaleidoscopic senses in the images of the ancient books and of the ancient wisdom. The new art awakens, therefore, the ancient art, and they, the two ones, unite themselves in a living memory.

The Big Snake is an image that is installed in the center of our imagination being. It is a bright ship that sails, during the dark nights, on the great river, and carries out the symbolization of the sparkling consciousness masters' dreams. In the words of Bachelar, water is a transitory element. As such, in Amazon water and man are privileged elements in the same greatness of meaning. Hence, this water psyche in us, carrying out all the emotional reason, as proved by the Amazon River dolphin legend, the cetacean which turns itself into man in the days of celebration and flirts with girls in the age of getting married.

In Images and Symbols, Eliade (1991) conceptualized the "myth as a narrative of events which have succeeded in principio, in the primordial beginning, timeless, in a lapse of sacred time" (p. 56). We know that man, after hearing the myth, forgets his profane condition, his historical situation, as we used to say. However, in our Amazon, this condition updates us in the beauty of the rite, bringing with it the light that seems to come from the unexpected and disturbing side of the reality. Because of the lightness brought, which exists only in the narrative act, myth shows its epiphanic beauty. The Big Snake is the light of the Amazon rivers, it is a bearer of sense and beauty by itself, completing itself in us.

\footnotetext{
3 Two sequential verses: (Jonah 2:1-2), Jonah, chapter 2, verses 1 and 2. King James Version (KJV). Available on: https://www.biblegateway.com/passage/?search=Jonah+2\&version=KJV (Accessed Jun 16 2017).
} 


\section{Conclusion}

As we know, there are nowadays several literary analysis methods at our disposal. We know, on the other hand, that interpretation must be sustained by the text, once text is a work open to all kinds of interpretative nuances. For this reason, the reader is able of discovering a plethora of connections as well as of dialoguing with the images that are at his disposal. I resorted here to Ricoeur's hermeneutics to dialogue with Engrácio, Amazonian author that presents in his works a multitude of issues to be studied.

Here, coming to an end, I have noticed that it is really possible to answer the disturbing question: Is there a literature from the State of Amazon? Yes, there is. There is not only a literature from the State of Amazon, but also a literature that must be read, studied, and investigated with sufficient goodwill, with the glance of a conqueror. Engrácio is an author that shows himself, at the same time, both as a reader and as a writer of his own life. In Santos' studies, for example, we have the idea about the experience of narration based on Ricoeur's view, that is: "it is that one which transforms memories into telling things, or consists of the configuration of life affairs into a plot, which in turn allows a new figuration of this same life, endowing it with a narrative identity which may be interpreted and comprehended" (Santos, 2010, p. 3).

\section{References}

Angenot, M. (1984). Glossário da criítica contemporânea (Modern criticism glossary). Tradução Miguel Tamen, Lisboa: Editorial Comunicação.

Bachelard, G. (2006). A poética do devaneio (A reverie poetry) (2nd ed.). Trad. Antonio de Pádua Danesi Ver, da Trad. Alain Marcel Mouzat, Mario Laranjeira. São Paulo: Martins Fontes.

Chevalier, J. A. G. (1990). Dicionário de Símbolos. Mitos, sonhos, costumes, gestos, formas, figuras, cores, números (Dictionary of symbols, myths, customs, gestures, forms, figures, colors, numbers) (2nd ed.). Coordenação Carlos Sussekind; trad. Vera da Costa e Silva [et al.]. Rio de Janeiro: José Olympio.

Eliade, M. (1991). Imagens e símbolos (Images and symbols). São Paulo: Martins Fontes.

Engrácio, A. (1986). 20 contos Amazônicos (20 Amazonian tales). Manaus: Edições Puxirum.

Fiorin, J. L. (2008). As astúcias da Enunciação. As categorias de pessoa, espaço e tempo (The astuteness of enunciation. People, space, and time categories). São Paulo: Editora Ática.

Foucault, M. (2001). Estética: Literatura e Pintura, Música e Cinema (Aesthetics: Literature and painting, music and cinema). Org. Manoel barros da Motta; Trad. Inês Autran Dourado Barbosa. Rio de Janeiro: Forense Universitária.

Loureiro, J. J. P. (2001). Obras reunidas Poesia I (Collected works poetry I). São Paulo: Escrituras Editora.

Paiva, R. (2005). Subjetividade e imagem: a literatura como horizonte da filosofia em Henri Bergson (Subjectivity and image: The literature as horizon of philosophy in Henri Bergson). São Paulo: Associação Editorial Humanitas, Fapesp.

Pignatari, D. (2004). Semiótica \& Literatura (Semiotics and literature) (6th ed.). Cotia, SP: Ateliê Editorial.

Ricoeur, P. (1994). Tempo e Narrativa. Tomo I (Time and narrative. Tome I). Campinas, SP: Papirus.

Ricoeur, P. (2000). A Teoria da interpretação: o discurso e o excesso de significação (Theory of interpretation: The discourse and the excess of meaning). Trad. Artur Morão. Edições 70, Lisboa-Portugal.

Santos, M. P. (2010). A compreensão do si mesmo e do outro em autobiografias: contribuições ricoeurianas na escrita da história (The understanding about the oneself and the othe one in autobiographies: Ricoeur's contributions to the writing of history). Revista da UAE História e Ciências Sociais, 2006, 1(5). Retrieved from https://doi.org/10.5216/emb.v1i2.11388

Sartre, J. P. (1984). A imaginação (The imagination). In: SARTRE. Rita Correia Guedes, Luiz Roberto Salinas Forte, Bento Prado Junior. São Paulo: Abril Cultural.

Teles, G. M. (1996). A ecrituração da escrita: teoria e prática do texto literário (The bookkeeping of the writing: Theory and practice of the literary text). Petrópolis, RJ: Vozes.

Tufic, J. (1982). Existe uma literatura amazonense? (Is there a literature from the state of Amazon?). Plano Editorial/Nordeste. Coleção Nordeste de Literatura União Brasileira de Escritores do Amazonas. 